\title{
LEVEL OF PHYSICAL ACTIVITY OF WOMEN AND MEN FROM INDEPENDENT CULTURAL CENTERS IN POLAND
}

\section{POZIOM AKTYWNOŚCI FIZYCZNEJ KOBIET I MĘŻCZYZN Z NIEZALEŻNYCH CENTRÓW KULTURY FUNKCJONUJĄCYCH NA TERENIE POLSKI}

\author{
Michał Bergier ${ }^{1(\mathrm{~A}, \mathrm{~B}, \mathrm{C}, \mathrm{D}, \mathrm{E}, \mathrm{F})}$, Barbara Bergier ${ }^{1(\mathrm{D}, \mathrm{E}, \mathrm{F})}$ \\ ${ }^{1}$ Department of Tourism and Recreation, Pope John Paul II State School of Higher Education in Biała Podlaska, Poland
}

Authors' contribution Wkład autorów:

A. Study design/planning zaplanowanie badań

B. Data collection/entry zebranie danych

C. Data analysis/statistics dane - analiza i statystyki D. Data interpretation interpretacja danych E. Preparation of manuscript przygotowanie artykułu F. Literature analysis/search wyszukiwanie i analiza literatury G. Funds collection zebranie funduszy
Tables: 4

Figures: 0

References: 32

Submitted: 2021 Jan 11

Accepted: 2021 Feb 22

\section{Summary}

Background. The aim of this study was to identify the level of physical activity of members of Independent Cultural Centers (ICCs) operating in Poland. The choice of this group was dictated by the desire to identify unconventional initiatives (including various types of physical activities) that differentiate the group from previously researched socio-professional groups. Material and methods. The study included participants from all ICCs in Poland, represented by 38 women and 66 men aged 19 to 46 years. To assess their level of physical activity, the short version of the International Physical Activity Questionnaire (IPAQ short) was used. Results. For both sexes, physical activity at intensity levels of vigorous (VPA), moderate (MPA), light (walking) (LPA), as well as the total physical activity (TPA) of the subjects, were measured. Among men, weekly VPA energy expenditure was 1281.2 MET-min/week (SD = 763.6) and among women 1162.7 MET-min/wk. (SD = 644.6). For MPA, analysis of the results showed an energy expenditure of 918.8 MET-min/week $(\mathrm{SD}=650.6)$ in women and 772.3 MET-min/week (SD = 455.5) in men. Weekly LPA energy expenditure was 1342 MET-min/ week in men (SD = 827.2) and 1341.3 MET-min/week in women (SD = 823.6).

Conclusions. Respondents from the ICCs constituted a group characterized by positive physical activity scores. Women had higher results compared to men in the VPA, MPA and TPA analyses, although these differences were not statistically significant. The respondents' results were also more favorable in relation to groups of students and members of other Polish associations and non-governmental organizations.

Keywords: physical activity, IPAQ, independent cultural centers

\section{Streszczenie}

Wprowadzenie. Celem badań było rozpoznanie poziomu aktywności fizycznej członków Niezależnych Centrów Kultury (NCK) funkcjonujących na terenie Polski. Wybór tej grupy podyktowany był chęcią podjęcia próby rozpoznania nieszablonowych inicjatyw (w tym zajęć ruchowych), różniących ją od dotychczas badanych grup społeczno-zawodowych.

Materiał i metody. W badaniu uwzględniono uczestników wszystkich aktywnie działających NCK na terenie Polski, reprezentowanych przez 38 kobiet i 66 mężczyzn w wieku od 19 do 46 lat. Do oceny poziomu aktywności fizycznej badanych, wykorzystano krótką wersję Międzynarodowego Kwestionariusza Aktywności Fizycznej (IPAQ short).

Wyniki. Rozpoznano aktywność fizyczną badanych obojga płci na poziomie intensywności wysokiej (VPA), umiarkowanej (MPA), niskiej (chodzenie) (LPA) oraz całkowitą aktywność fizyczną (TPA) badanych. Wśród mężczyzn tygodniowy wydatek energetyczny VPA wynosił 1281,2 MET-min/tydz. (SD = 763,6), wśród kobiet 1162,7 MET-min/tydz. $(S D=644,6)$. W przypadku MPA analiza wyników wykazała wydatek energetyczny na poziomie 918,8 METmin/tydz. $(S D=650,6)$ u kobiet i 772,3 MET-min/tydz. $(S D=455,5)$ u mężczyzn. Tygodniowy wydatek energetyczny LPA wynosił 1342 MET-min/tydz. u mężczyzn (SD = 827,2) i 1341,3 MET-min/tydz. u kobiet $(\mathrm{SD}=823,6)$.

Wnioski. Respondenci z NCK byli grupą charakteryzującą się korzystnymi wynikami aktywności fizycznej. Kobiety uzyskały rezultaty wyższe w porównaniu do mężczyzn w analizach VPA, MPA oraz TPA choć nie były to różnice statystycznie istotne. Wyniki respondentów były także korzystniejsze, w odniesieniu do grup studentów oraz członków innych polskich stowarzyszeń i organizacji pozarządowych.

Słowa kluczowe: aktywność fizyczna, IPAQ, niezależne centra kultury 


\section{Introduction}

Independent Cultural Centers (ICCs) are an example of people affiliated to associations who engage in a variety of initiatives, both socio-cultural as well as recreational and sporting, which promote physical activity. Such initiatives are undertaken in a grassroots manner by members of individual ICCs, who also participate in the above-mentioned activities. The numerous publications on various socio-professional groups that have been studied in terms of physical activity, combined with the lack of studies on people from ICCs, were the motivation for conducting this study on the physical activity of these niche groups in Poland. Physical activity, as studies have shown, has an undeniable positive impact on our health. The analyses carried out have demonstrated beneficial results both in terms of physical and mental health across different age groups. Regular physical activity undertaken at an appropriate level of intensity has a positive effect on, among other things, issues affecting entire populations as well as those related to being overweight, diabetes, depression, as well as the risk of developing cancer and mortality in people with cancer [1-8]. Physical activity may therefore be one of the best and most accessible preventive tools against the risks of progressive diseases of civilization [9-14]. The positive benefits of physical activity have also been highlighted during the current COVID-19 pandemic [15-18]. Analyses of current issues have resulted in World Health Organization (WHO) recommendations for physical activity to be undertaken in home isolation involving exercise on stationary bicycles, ergometers, forms of dance, games that stimulate participants, as well as performing bodyweight exercises. The intensity of individual activities is tailored to different age groups [19].

Previous publications contain information on the physical activity levels of different socio-professional groups [20-24]. The challenge for further research on physical activity is to reach previously unexplored groups and groups that are active in unconventional, often niche ways. The following work concerns the physical activity of people affiliated with ICCs. The decision to choose this research group was motivated by the search for unusual initiatives that promote physical activity and, consequently, a healthy lifestyle as an effective method of health protection. The activities undertaken by such groups, including physical fitness initiatives, can serve as a good comparison and perhaps also as a source of inspiration as to how individual groups can be encouraged to engage in physical activity. Members of individual ICCs organize, as well as actively participate in, physical fitness activities. They are, therefore, a good example of self-organization, which results, among other things, in increased health. The aim of this study is to identify the level of physical activity of the men and women affiliated with four ICCs in Poland.

\section{Material and methods}

The research material consisted of members of four actively operating ICCs located in Warsaw, Lublin, Gliwice and Wroclaw. These centers are legal entities, operating as the following associations:

- Association for the Reanimation of Alternative Culture, based in Wroclaw, at Jagiellończyka st. 10 c/d,

- Ecological, Cultural and Freedom Association "Krzyk," based in Gliwice, at Jana Śliwki st. 13,

- The voluntary association "Skłotpol," based in Warsaw at Puławska st. 37,

- The voluntary association "Sztukon", based in Lublin at Puławska st. 9D.

The individual centers have been operating for between 2 and 11 years. Their common feature is the fact that they are non-governmental organizations, acting in a grassroots manner, following the Do It Yourself (D.I.Y.) principle. The research took place in four ICCs, which, as a result of direct interviews with individual members, turned out to be the only actively operating centers of this kind in Poland. In order to reach as many people as possible, the research was carried out during general meetings of the members of individual associations. It is estimated that as many as $90 \%$ of persons belonging to particular organizations took part in these meetings, which constitutes a representative group. A total of 104 subjects were studied, including 38 women and 66 men aged 19 to 46 years. The short version of the International Physical Activity Questionnaire (IPAQ), supplemented with demographic questions, was used to assess physical activity. This tool allowed the identification of vigorous (VPA), moderate (MPA) and low (LPA) intensities of physical activity, as well as total physical activity (TPA), undertaken by the respondents in the seven (typical) days preceding the survey. The final results of the selfassessed weekly volume of physical activity were expressed in MET-min/week, obtained by multiplying the coefficient assigned to the activity by the number of days of activity in the seven days analyzed prior to the survey and the duration expressed in minutes [25].

The most applicable non-parametric statistical methods were used to analyze physical activity levels. The significance of differences between the study variables for independent samples was determined with the MannWhitney U test, which is equivalent to the classical Student's t-test for unrelated samples. The distributions of 
the variable $(\mathrm{k}>2)$ in the populations were tested using the Kruskal-Wallis rank-sum test. This test does not assume the normality of distributions. It is considered a non-parametric alternative to the one-way analysis of variance between groups.

\section{Results}

\section{Vigorous physical activity}

A comparison of the frequency of vigorous physical activity (VPA) by women and men from ICCs showed similar levels of the analyzed indicators during the week. Also, in the case of the volume of such exercise, it was shown that women performed this type of exercise on average on 3.7 days of the week, while men performed it on 3.6. For women, the volume of VPA averaged 50 minutes per day (SD = 27.6). In men, on the other hand, it was 41 minutes (SD = 15.8). On a weekly basis, the declared time to perform VPA was 160 minutes (SD = 95.4) for women and 145 minutes ( $S D=80.6)$ for men, respectively. Weekly energy expenditure for VPA was 1281.2 MET$\mathrm{min} /$ week $(\mathrm{SD}=763.6)$ for women and 1162.7 MET-min/week (SD = 644.6) for men (Table 1).

Table 1. VPA undertaken by men and women from ICCs

\begin{tabular}{|c|c|c|c|c|c|c|c|}
\hline Variable & Group & $\mathbf{n}$ & $\overline{\mathbf{x}}$ & SD & $\sum R$ & $\mathbf{U}$ & $\mathbf{P}$ \\
\hline \multirow{2}{*}{ VPA [days/week] } & $\mathrm{W}$ & 34 & 3.7 & 2.0 & 1599.0 & \multirow{2}{*}{1002.0} & \multirow{2}{*}{0.997} \\
\hline & $\mathrm{M}$ & 59 & 3.6 & 1.6 & 2772.0 & & \\
\hline \multirow{2}{*}{ VPA [min/day] } & $\mathrm{W}$ & 34 & 49.7 & 27.6 & 1734.0 & \multirow{2}{*}{867.0} & \multirow{2}{*}{0.280} \\
\hline & $\mathrm{M}$ & 59 & 41.4 & 15.8 & 2637.0 & & \\
\hline \multirow{2}{*}{ VPA [min/week] } & $\mathrm{W}$ & 34 & 160.1 & 95.4 & 1683.0 & \multirow{2}{*}{918.0} & \multirow{2}{*}{0.500} \\
\hline & $\mathrm{M}$ & 59 & 145.3 & 80.6 & 2688.0 & & \\
\hline \multirow{2}{*}{ VPA [MET-min/week] } & $\mathrm{W}$ & 34 & 1281.2 & 763.6 & 1683.0 & \multirow{2}{*}{918.0} & \multirow{2}{*}{0.500} \\
\hline & $\mathrm{M}$ & 59 & 1162.7 & 644.6 & 2688.0 & & \\
\hline
\end{tabular}

Notes: $\mathrm{n}$ - number of cases, $\overline{\mathrm{x}}$ - arithmetic mean, $\mathrm{SD}$ - standard deviation, $\sum \mathrm{R}$ - rank-sum, $\mathrm{U}$ - Mann-Whitney test value, $\mathrm{p}$ test probability level for U, VPA - vigorous physical activity (8.0 METs), W - women, M - men.

\section{Moderate physical activity}

Analysis of moderate physical activity (MPA) declared by the respondents during the 7 days preceding the survey revealed tendencies similar to those for VPA. This is confirmed by both frequency and volume indices. On average, representatives of both sexes declared undertaking moderate intensity efforts on 4 days of the week (women on 4.2 and men on 4 days). The results of the daily volume of such efforts were also very similar. They averaged 58 minutes (SD $=29.3)$ in women and 52 minutes (SD = 24.7) in men. In contrast, the weekly volume of MPA was 229 (SD = 162.6) for women and 193 minutes (SD = 113.9) for men. Weekly energy expenditure for MPA was 918.8 MET-min/week (SD = 650.6) for women and 772.3 MET-min/week (SD = 455.5) for men (Table 2).

Table 2. MPA undertaken by men and women from ICCs

\begin{tabular}{|c|c|c|c|c|c|c|c|}
\hline Variable & Group & $\mathbf{n}$ & $\overline{\mathbf{x}}$ & SD & $\sum \mathrm{R}$ & $\mathbf{U}$ & $\mathbf{p}$ \\
\hline \multirow{2}{*}{ MPA [days/week] } & $\mathrm{W}$ & 33 & 4.2 & 2.0 & 1571.5 & \multirow{2}{*}{870.5} & \multirow{2}{*}{0.561} \\
\hline & $\mathrm{M}$ & 57 & 4.0 & 2.1 & 2523.5 & & \\
\hline \multirow{2}{*}{ MPA [min/day] } & $\mathrm{W}$ & 33 & 57.9 & 29.3 & 1602.5 & \multirow{2}{*}{839.5} & \multirow{2}{*}{0.400} \\
\hline & $\mathrm{M}$ & 57 & 52.0 & 24.7 & 2492.5 & & \\
\hline \multirow{2}{*}{ MPA [min/week] } & $\mathrm{W}$ & 33 & 229.7 & 162.6 & 1595.0 & \multirow{2}{*}{847.0} & \multirow{2}{*}{0.436} \\
\hline & $\mathrm{M}$ & 57 & 193.1 & 113.9 & 2500.0 & & \\
\hline \multirow{2}{*}{ MPA [MET-min/week] } & W & 33 & 918.8 & 650.6 & 1595.0 & \multirow{2}{*}{847.0} & \multirow{2}{*}{0.436} \\
\hline & $\mathrm{M}$ & 57 & 772.3 & 455.5 & 2500.0 & & \\
\hline
\end{tabular}

Notes: $\mathrm{n}$ - number of cases, $\overline{\mathrm{x}}$ - arithmetic mean, $\mathrm{SD}$ - standard deviation, $\sum \mathrm{R}$ - rank-sum, $\mathrm{U}$ - Mann-Whitney test value, $\mathrm{p}$ test probability level for U, MPA - moderate physical activity (4.0 METs), W - women, M - men.

\section{Light physical activity}

Light physical activity (LPA) was reported more frequently in women (relative to men). Women declared performing LPA on 6.3 (SD = 1.4) days of the week, while men declared performing LPA on 6.1 (SD = 1.7) days of 
the week. In contrast, analysis of LPA volume showed a more favorable result for men. They declared engaging in low-intensity physical activity an average of 67 minutes per day (SD = 36.2). Women, on the other hand, 62 minutes (SD = 35.7). This small difference was also confirmed by the results of the analyses of weekly LPA volume, equal to 406.7 ( $S D=250.7)$ minutes in men and $406.4(\mathrm{SD}=249.6)$ minutes in women. The weekly energy cost of low-intensity physical activity was 1342 MET-min/week in men (SD = 827.2) and 1341.3 MET$\mathrm{min} /$ week in women $(\mathrm{SD}=823.6)$ (Table 3).

Table 3. LPA undertaken by men and women from ICCs

\begin{tabular}{|c|c|c|c|c|c|c|c|}
\hline Variable & Group & $\mathbf{n}$ & $\overline{\mathbf{x}}$ & SD & $\sum \mathrm{R}$ & $\mathbf{U}$ & $\mathbf{p}$ \\
\hline \multirow{2}{*}{ LPA [days/week] } & $\mathrm{W}$ & 38 & 6.3 & 1.4 & 1993.5 & \multirow{2}{*}{1141.5} & \multirow{2}{*}{0.700} \\
\hline & $\mathrm{M}$ & 63 & 6.1 & 1.7 & 3157.5 & & \\
\hline \multirow{2}{*}{ LPA [min/day] } & $\mathrm{W}$ & 38 & 62.0 & 35.7 & 1828.5 & \multirow{2}{*}{1087.5} & \multirow{2}{*}{0.445} \\
\hline & $\mathrm{M}$ & 63 & 67.4 & 36.2 & 3322.5 & & \\
\hline \multirow{2}{*}{ LPA [min/week] } & $\mathrm{W}$ & 38 & 406.4 & 249.6 & 1965.5 & \multirow{2}{*}{1169.5} & \multirow{2}{*}{0.850} \\
\hline & $\mathrm{M}$ & 63 & 406.7 & 250.7 & 3185.5 & & \\
\hline \multirow{2}{*}{ LPA [MET-min/week] } & $\mathrm{W}$ & 38 & 1341.3 & 823.6 & 1965.5 & \multirow{2}{*}{1169.5} & \multirow{2}{*}{0.850} \\
\hline & $\mathrm{M}$ & 63 & 1342.0 & 827.2 & 3185.5 & & \\
\hline
\end{tabular}

Notes: $\mathrm{n}$ - number of cases, $\overline{\mathrm{x}}$ - arithmetic mean, $\mathrm{SD}$ - standard deviation, $\sum \mathrm{R}$ - rank-sum, $\mathrm{U}$ - Mann-Whitney test value, $\mathrm{p}$ test probability level for U, LPA - light physical activity (3.3 METs) W - women, M - men.

\section{Total physical activity}

A summary of the physical activity performed by the respondents from ICCs in Poland was provided by the analysis of total physical activity (TPA) that the respondents declared during the previous week. In this case, women showed more favorable results than men. According to the analyses, women declared on average 156 minutes (SD $=67.5$ ) of physical activity per day and 749 minutes (SD $=408.6)$ per week. The score obtained by men was 150 minutes ( $S D=57.0)$ and 706 minutes (SD = 304.1), respectively. As the analyses showed, the total energy cost of TPA was 3285.5 MET-min/week (SD = 1769.3) for women and 3080.7 MET-min/week (SD = 1239.1) in men (Table 4).

Table 4. TPA undertaken by men and women from ICCs

\begin{tabular}{|c|c|c|c|c|c|c|c|}
\hline Variable & Group & $\mathbf{N}$ & $\overline{\mathbf{x}}$ & SD & $\sum \mathbf{R}$ & $\mathbf{U}$ & $\mathbf{P}$ \\
\hline \multirow{2}{*}{ TPA [min/day] } & W & 38 & 156.7 & 67.5 & 2021.0 & \multirow{2}{*}{1152.0} & \multirow{2}{*}{0.660} \\
\hline & $\mathrm{M}$ & 64 & 150.8 & 57.0 & 3232.0 & & \\
\hline \multirow{2}{*}{ TPA [min/week] } & $\mathrm{W}$ & 38 & 749.2 & 408.6 & 1975.5 & \multirow{2}{*}{1197.5} & \multirow{2}{*}{0.901} \\
\hline & M & 64 & 706.3 & 304.1 & 3277.5 & & \\
\hline \multirow{2}{*}{ TPA [MET-min/week] } & $\mathrm{W}$ & 38 & 3285.5 & 1769.3 & 1986.5 & \multirow{2}{*}{1186.5} & \multirow{2}{*}{0.841} \\
\hline & $\mathrm{M}$ & 64 & 3080.7 & 1239.1 & 3266.5 & & \\
\hline
\end{tabular}

Notes: $\mathrm{n}$ - number of cases, $\overline{\mathrm{x}}$ - arithmetic mean, SD - standard deviation, $\sum \mathrm{R}$ - rank-sum, $\mathrm{U}$ - Mann-Whitney test value, $\mathrm{p}$ test probability level for $\mathrm{U}, \mathrm{TPA}$ - total physical activity, $\mathrm{W}$ - women, $\mathrm{M}$ - men.

\section{Discussion}

The direct interviews conducted, the identification of the profiles of the respondents and their initiatives, as well as their comparison with other groups of respondents researched so far in terms of physical activity, show that the groups of people affiliated to ICCs are an example of atypical, grassroots organizations undertaking, among other things, initiatives related to physical culture. From a research point of view, they are very interesting groups because of the effects of their activities, which were expressed by the level of physical activity of the ICC members. As shown in the conducted analyses, the average level of physical activity of men and women from ICCs was higher compared to student groups [26,27], similar to the level shown in members of Polish nongovernmental organizations promoting recreational physical activity [28] and a health-promoting association from Zagłębie Dąbrowskie [29]. Analyses of the results obtained from the ICC respondents showed that although there were no statistically significant differences in the level of physical activity between men and women, the results obtained were more favorable in women. This was true for VPA and MPA, as well as for the TPA of the respondents. These types of results are rare [30,31], with men's physical activity levels being higher than women's in most publications [32]. 
The results obtained allow us to assume that the group of people affiliated with ICCs is an atypical social (research) group.

The results showing no statistically significant differences between men's and women's levels of physical activity may indicate that both men and women find an appropriate range of leisure activities through the ICCs and therefore achieve similar levels of physical activity.

\section{Conclusions}

1. People from ICCs showed favorable levels of physical activity compared to other socio-occupational groups.

2. Despite a lack of statistically significant variation, women obtained more favorable results than men for VPA, MPA and TPA.

3. ICCs undertake a range of initiatives, including those related to the promotion of the physical activity. They are, therefore, excellent examples of grassroots health promotion initiatives.

4. There is a need for further research into ICCs to gain a clearer understanding of the types and forms of physical activity undertaken and how it is promoted.

\section{References:}

1. Warburton DER, Bredin SSD. Health benefits of physical activity: a strengths-based approach. J Clin Med. 2019; 12(8): 20-44. https://doi.org/10.3390/jcm8122044

2. San Román-Mata S, Puertas-Molero P, Ubago-Jiménez JL, González-Valero G. Benefits of physical activity and its associations with resilience, emotional intelligence, and psychological distress in university students from southern Spain. Int J Environ Res Public Health. 2020; 12(17): 44-74. https://doi.org/10.3390/ijerph17124474

3. Jakicic JM, Kraus WE, Powell KE, Campbell WW, Janz KF, Troiano RP, et al. Association between bout duration of physical activity and health: systematic review. Medicine and Science in Sports and Exercise. 2019; 51(6): 1213-1219. https://doi.org/10.1249/MSS.0000000000001933

4. Dipietro L, Evenson KR, Bloodgood B, Sprow K, Troiano RP, Piercy KL, et al. Benefits of physical activity during pregnancy and postpartum: an umbrella review. Medicine and Science in Sports and Exercise. 2019; 51(6): 1292-1302. https://doi.org/10.1249/MSS.0000000000001941

5. Kubińska Z, Pańczuk A. [Health benefits from physical activity undertaken by elderly people]. Edukacja Ustawiczna Dorosłych. 2019; 3: 51-61 (in Polish). https://doi.org/10.34866/m0ec-eg63

6. Dyrla-Mularczyk K, Giemza-Urbanowicz W. [The influence of physical activity on the functioning of the nervous system and cognitive processes - research review]. Neuropsychiatria i Neuropsychologia. 2019; 14(3-4): 84-91 (in Polish). https://doi.org/10.5114/nan.2019.89792

7. Mc Tiernan A, Friedenreich CM, Katzmarzyk PT, Powell KE, Macko R, Buchner D, et al. Physical activity in cancer prevention and survival: a systematic review. Medicine and Science in Sports and Exercise. 2019; 51(6): 1252-1261. https://doi.org/10.1249/MSS.0000000000001937

8. Biddle SJH, Ciaccioni S, Vergeer GTI. Physical activity and mental health in children and adolescents: an updated review of reviews and an analysis of causality. Psychology of Sport and Exercise. 2019; 42: 146-155. https://doi.org/10.1016/j.psychsport.2018.08.011

9. Bień Ł. [Impact of recreational physical activity on social and economic aspects of national security in literature]. Progress. Journal of Young Researchers. 2019; 6: 126-146 (in Polish). https://doi.org/10.26881/prog.2019.6.10

10. Lipińska-Ojrzanowska A, Magnuska J, Świerczyńska-Machura D, Walusiak-Skorupa J, Marcinkiewicz A, Wiszniewska M. [Workers' view on the preventive needs for civilization diseases' in prophylactic care taken on employees]. Medycyna Pracy. 2019; 70(4): 425-433 (in Polish). https://doi.org/10.13075/mp.5893.00821

11. Synowiec-Piłat M, Jędrzejek M, Pałęga A. [Promotion of recreational physical activity as a challenge for health promotion targeted at the local community: a study of Wrocław residents]. In: Borcuch A, Knefel M, Krzysztofek A., editors. [Healthy lifestyle as the 21st century capital]. Kielce: Laboratorium Wiedzy Artur Borcuch; 2019. p. 53-61 (in Polish).

12. Delepeuch F, Maire B, Monnier E, Holdsworth M. Globesity: a planet out of control?. Sterling, VA: Earthscan Publications; 2009.

13. Mleczko E, Gradek J, Januszewski J. [Overweight and obesity as methodological problem. Diagnosis of the epidemic in the world]. Antropomotoryka. 2011; 21(53): 95-106 (in Polish). 
14. Recio-Rodríguez J, Sanchez-Aguadero N, Rodríguez-Sánchez E, Martinez-Vizcaino V, Martin-Cantera C, Patino-Alonso MC, et al. Physical activity and adiposity among older adults of the evident study. Journal of Aging \& Physical Activity. 2017; 25(2): 254-260. https://doi.org/10.1123/japa.2016-0065

15. Gawda P, Zieliński G, Zawadka M, Byś A. [Health training - preparing an organism for coping with COVID-19]. Pol J Public Health. 2019; 129(4): 132-137 (in Polish). https://doi.org/10.2478/pjph-2019-0030

16. Maugeri G, Castrogiovannia P, Battagliab G, Pippic R, D’Agataa V, Palmab A, et al. The impact of physical activity on psychological health during Covid-19 pandemic in Italy. Heliyon. 2020; 6(6): e04315. https://doi.org/10.1016/j.heliyon.2020.e04315

17. Woods JA, Hutchinsona NT, Powers SK, Roberts WO, Gomez-Cabrera MC, Radak Z. The COVID-19 pandemic and physical activity. Sports Medicine and Health Science. 2020; 2(2): 55-64. https://doi.org/10.1016/j.smhs.2020.05.006

18. Amatriain-Fernández S, Murillo-Rodríguez ES, Gronwald T, Machado S, Budde H. Benefits of physical activity and physical exercise in the time of pandemic. Psychological Trauma: Theory, Research, Practice, and Policy. 2020; 12(S1): 264-266. https://doi.org/10.1037/tra0000643

19. Hammami A, Harrabi B, Mohr M, Krustrup P. Physical activity and coronavirus disease 2019 (COVID-19): specific recommendations for home-based physical training. Managing Sport and Leisure. 2020. https://doi.org/10.1080/23750472.2020.1757494

20. Biernat E. [Physical activity of inhabitants of Warsaw. A study of some professional groups]. Warszawa: Szkoła Główna Handlowa; 2011 (in Polish).

21. Gajda R. [Level of physical activity in comparison to selected eating habits of women]. Sport i Turystyka Środkowoeuropejskie Czasopismo Naukowe. 2020; 3(1): 147-164 (in Polish). https://doi.org/10.16926/sit.2020.03.09

22. Łysak A, Walentukiewicz A, Drabik J, Dąbrowski A, Rowiński R. [Physical activity and its determinants in senior population of Pomeranian region]. Hygeia Public Health. 2014, 49(3): 549-553 (in Polish).

23. Jabłońska Ż, Tomaszewski W. Physical activity of Polish population living in Poland as compared with Poles living in the UK. Polish Journal of Sports Medicine / Medycyna Sportowa. 2020; 36(2): 73-84.

24. Wojciechowski L, Bergier M. Physical activity of the Biała Podlaska prison staff and its conditioning factors. Health Prob Civil. 2016; 10(3): 47-56. https://doi.org/10.5114/hpc.2016.61366

25. Biernat E, Stupnicki R, Gajewski AK. [International Physical Activity Questionnaire (IPAQ) - Polish version]. Wychowanie Fizyczne i Sport. 2007; 51: 47-54 (in Polish).

26. Bergier B, Stępień E, Niźnikowska E, Bergier J. [Physical activity of male and female students of the State Higher Vocational School in Biała Podlaska, Poland]. Medycyna Ogólna i Nauki o Zdrowiu. 2014; 20(2): 166170 (in Polish). https://doi.org/10.5604/20834543.1112232

27. Walentukiewicz A, Łysak A, Wilk B. [Physical activity of nursing students]. Rocznik Naukowy. 2015; 15: 2428 (in Polish).

28. Dębska M, Mynarski W, Biernat E, Nawrocka A, Bergier J. Compliance with physical activity health recommendations in members of non-governmental organizations promoting active life style. Annals of Agricultural and Environmental Medicine. 2018; 26(1): 109-113. https://doi.org/10.26444/aaem/94293

29. Dębska M, Mynarski W, Rozpara M, Puciato D. Habitual physical activity in adults measured by accelerometer in compliance with selected health recommendations. Central European Journal of Sport Sciences and Medicine. 2017; 18(2): 99-105. https://doi.org/10.18276/cej.2017.2-10

30. Baj-Korpak J, Soroka A, Korpak F. Physical activity of selected socio-occupational groups (education). Człowiek i Zdrowie / Human and Health. 2010; 4(1): 152-171.

31. Pedišić Ž, Rakovac M, Bennie J, Jurakić D, Bauman AE. Levels and correlates of domain-specific physical activity in university students: cross-sectional findings from Croatia. Kinesiology. 2014; 46: 12-22.

32. Looze M, Elgar FJ, Currie C, Kolip P, Gonneke D, Stevens WJM. Gender inequality and sex differences in physical fighting, physical activity, and injury among adolescents across 36 countries. Journal of Adolescent Health. 2019; 64(5): 657-663. https://doi.org/10.1016/j.jadohealth.2018.11.007 